Curr Opin Microbiol. 2015 April ; 24: 21-28. doi:10.1016/j.mib.2014.12.007.

\title{
On The Evolution of Bacterial Multicellularity
}

\author{
Nicholas A. Lyons and Roberto Kolter \\ Department of Microbiology and Immunobiology, Harvard Medical School, 77 Avenue Louis \\ Pasteur, Boston, MA 02115
}

\begin{abstract}
Multicellularity is one of the most prevalent evolutionary innovations and nowhere is this more apparent than in the bacterial world, which contains many examples of multicellular organisms in a surprising array of forms. Due to their experimental accessibility and the large and diverse genomic data available, bacteria enable us to probe fundamental aspects of the origins of multicellularity. Here we discuss examples of multicellular behaviors in bacteria, the selective pressures that may have led to their evolution, possible origins and intermediate stages, and whether the ubiquity of apparently convergent multicellular forms argues for its inevitability.
\end{abstract}

\section{Introduction}

The universe can be viewed as a series of levels of organization based loosely on size. Inorganically, this includes the organization of different sub-atomic particles into atoms, which themselves can combine in various ways to form molecules with properties very different and unpredictable from their component parts. Thus, chemistry is derived from physics but remains distinct due to the distinguishable behaviors of molecules and their constituent parts.

Analogously, biology spans many levels of organization that also take on emergent properties at each stage (macromolecules to cells to multicellular organisms to societies and ecosystems). The major distinction of biology from the inorganic world, however, is the driving force behind each higher level: protons, neutrons, and electrons combine to form atoms based solely on their physical properties, whereas biological organization is additionally driven by fitness constraints. Each development must serve a function and the success of this function is determined not only by physical parameters but by natural selection. The evolution of life on this planet has gone through many of these leaps in organizational complexity [1]. To understand how we got to the remarkably complex biosphere extant today it is necessary to know both how (molecular mechanisms, "proximate causes") and why (selective advantages, "ultimate causes") these leaps occur.

() 2015 Elsevier Ltd. All rights reserved.

Correspondence: rkolter@hms.harvard.edu, 617-432-1776.

Publisher's Disclaimer: This is a PDF file of an unedited manuscript that has been accepted for publication. As a service to our customers we are providing this early version of the manuscript. The manuscript will undergo copyediting, typesetting, and review of the resulting proof before it is published in its final citable form. Please note that during the production process errors may be discovered which could affect the content, and all legal disclaimers that apply to the journal pertain. 
Of all the transitions between levels of organization, the advent of multicellularity is perhaps the most interesting for several reasons. Multicellularity completely redefines the concept of what is an individual organism, and has occurred independently dozens of times across all domains of life. Multicellularity represents a transition from the microscopic to the macroscopic world, and by being large, multicellular organisms are differentially affected by physical laws. For example, gravity becomes more important and Brownian motion less important, reminiscent of the transition from the atomic world driven by quantum mechanics to the chemistry-driven world of the cell. Multicellularity also enabled vast phenotypic expansion and diversification, primarily via cell differentiation and temporal development of morphological structures within an organism. And finally, multicellularity is most likely a necessary step along the evolutionary path to intelligence and consciousness.

Like the attempt to define "life", defining multicellularity is a tenuous endeavor, often clouded by anthropocentrism. However, there are two basic factors necessary to be considered a multicellular organism: cell-cell adhesion to form a new evolutionary unit, and intercellular communication leading to coordinated activity. Many elaborations have been evolved on top of this, but these are the minimal requirements to redefine a group of cells rather than any single cell as an "individual". Adhesion is a loose term used here solely to indicate conglomeration by any means, such as aggregation within an extracellular matrix, filamentation by incomplete cell division, or direct contact mediated by transmembrane proteins. Coordination within a multicellular organism could theoretically be achieved without intercellular communication, for example if a strict developmental plan was encoded in each genome. But such a rigid plan would be vulnerable to slight deviations or random variables, and has never been observed. In contrast, coordination can be achieved without adhered group formation - typified by quorum sensing systems found throughout the microbial world - but this is more analogous to a community of interacting individuals (like many insect colonies) than the formation of a single multi-celled unit.

Many examples of species and life cycles put this definition of multicellularity to the test. Chief among the borderline cases are the widespread examples of multicellularity in the bacterial domain. Long considered the archetypal unicellular organisms, bacteria have become popular as ideal model systems in which to explore the phenomenon of multicellularity [2]. Multicellular bacteria are well suited to laboratory study of multicellularity precisely because they are rather simple examples of this evolutionary innovation. Studying simpler examples or alternative origins allows us to get to the core of what enables fundamental evolutionary advancements, similar to primitive "nuclei" in planctomycete bacteria [3], neurons in ctenophores [4,5], or language in dolphins [6]. Therefore, bacterial multicellularity opens up to serious questioning the major issues of what selective forces lead to multicellular beings, the genetic underpinnings and their evolutionary history, and why this particular leap in organizational level is so recurrent.

\section{Classes of multicellular bacteria}

There are three very general classes of multicellularity in bacteria (Table 1). The first is comprised of filamentous bacteria, which are long chains of cells joined end-to-end that often share a periplasm or even cytoplasm. The most-studied members of this class are the 
cyanobacteria and the actinomycetes, but numerous other species from many phyla have been found to form filaments either conditionally or obligately [7]. Filaments can be linear or branched, single or multiple layers, and arise from a clonal origin. This is important, as clonality overcomes many of the genomic conflicts that come from a cooperative existence, especially given the high degree of public-goods sharing that comes with a continuous periplasm [8]. Filamentous microbes were likely the first multicellular organisms on Earth some 3 billion years ago [9] and the first known instance of cellular differentiation [10-12].

Another broad class of multicellular bacteria includes those that assemble into a multicellular organism via aggregation. These aggregates include biofilms and swarms, and are also found throughout the bacterial domain. (This group is not mutually exclusive with the first class, as filaments of cells are often found in biofilms and swarms [13,14]).

Biofilms have been very well characterized in the past few decades owing to their prominent role in disease and may be the primary context in which many bacteria exist in nature [15]. Formation of biofilms and swarms involves a complex developmental cascade of signaling and regulatory molecules, producing distinct morphologies and cell types [13]. Some species even form complex features such as mushroom-like structures [16,17] and fruiting bodies that contain spores functioning as a sort of germline [18]. As the name of this category suggests, these organisms form via aggregation of many cells that are held together via an extracellular matrix usually consisting of polysaccharides, proteins, and nucleic acids [19], though cells in swarms can also be attached by their numerous flagella [14]. Because they form by aggregation, these groups need not be clonal and thus are intriguing test beds for theories of the evolution and maintenance of cooperation, altruism, exploitation prevention, kin discrimination, and allorecognition [20]. Despite the problems associated with nonclonal aggregation, its prevalence may owe in part to the advantages that can come with some genomic variability [21].

The third multicellular class is the least studied and least represented - they are also the only truly obligate multicellular bacteria known to exist. This group is referred to as the multicellular magnetotactic prokaryotes (MMPs), so-named because nearly all the discovered examples are magnetotactic. MMPs are delta-proteobacteria isolated from around the world, and tend to be spheres or ellipsoids 5-10 $\mu \mathrm{m}$ in diameter containing about 20-60 cells [22-29]. The tetrahedral-shaped cells are arranged in a single layer with their flagellated base facing the environment and their narrower ends facing inward [30,31], creating an apparently hollow cavity reminiscent of the Volvocaceae algae [32]. By electron microscopy the cells of an MMP appear to be connected by tight intercellular junctions similar to animal epithelia [33], and dislodgement of any individual cells leads to loss of motility, suggesting these organisms can only function as a multicellular unit [30]. MMPs have been observed to reproduce by fission of the whole organism without going through a unicellular state $[23,24,28]$, making it the only known example of a bacterium without a unicellular phase in its lifecycle. Many fundamental aspects of MMP biology remain to be determined, including what mediates cell-cell attachment, what types of intercellular signaling is used to coordinate movement, and how reproduction is orchestrated. 


\section{Selective advantages of multicellularity}

Key to understanding how multicellularity evolved will be pinpointing the selective pressures that lead to its fixation in so many species. There are inherent disadvantages to operating as a collective group rather than a single cell. These include energetic costs from the synthesis of adhesion and communication molecules, physical limitations from reduced freedom of movement, as well as the less tangible vulnerability of a cooperative system to exploitation by "cheaters" [20]. The commonness of conditional multicellularity may be a response to these costs, analogous to the way many biosynthetic gene clusters are only expressed upon certain stimuli. The advantages of multicellularity are numerous though: resistance to physical and chemical stresses, improved acquisition of resources, protection from predation, more efficient colonization of new territories, increased chance of survival in intermicrobial conflicts, and the opportunity for cell differentiation and thus specialization among different cell types. As discussed in the next section, many of these benefits arise primarily from the physical adhesion of cells to create a larger, more protected unit.

Resistance to environmental stresses appears to be the most common advantage enjoyed by multicellular bacteria. The list of stresses against which multicellularity affords a defense is long and varied [7,34], including temperature, $\mathrm{pH}$, osmotic pressure, oxidation, desiccation, metal toxicity, and mechanical forces. The extracellular matrix is responsible for much of this resistance [19], but much of the effectiveness of the matrix may result from its communal origins-a population of single cells uncoordinatedly secreting matrix would probably not have the same benefits as a well-organized aggregate. The evolution of multicellularity as a stress response is an intriguing idea as it puts it in a category shared with other significant evolutionary advances. For example, meiosis in eukaryotes may have originally been a response to adverse conditions or accidental increases in ploidy [35]. Likewise, recombination enzymes that evolved to repair damaged DNA were co-opted to share DNA and shuffle genes within a population, greatly accelerating the rate of evolution [36].

Multicellular organisms are also better at nutrient utilization. This comes in many different and fascinating flavors, a few of which we will mention here. In predatory bacteria, swarms of cells are better able to capture and consume prey than non-swarming mutants [37]. This is also seen in choanoflagellates, which, upon sensing certain bacteria, form multicellular clusters that can cast a wider "net" to more efficiently capture the prey [38]. Along the ocean floor, filaments of Desulfobulbaceae stretch from upper regions of sediment that are rich in oxygen to lower anoxic regions favorable for oxidation of hydrogen sulfide, with electrons transported along the filament like a wire [39]. This remarkable behavior allows the organism to be its own electron source and sink, powering itself on naturally occurring redox gradients. In biofilms, nutrients can be dispersed through channels that course through the biofilm like veins in the human body [40]. Some bacteria even form vertical structures in biofilms that can reach above the local nutrient depletion of the mat $[16,17,41]$ in the way trees in a forest vie to be tallest to receive the most sunlight. Lastly, cells in groups can better take up extracellularly-produced resources that would otherwise diffuse away [4244], a tactic that single cells would find both inefficient and susceptible to freeloaders. 
Another strong selective force with a direct effect on survival of multicellular over unicellular organisms is predation, in both classic predator-prey relationships as well as phagocytosis by host immune system cells. Many studies have found that filamentous bacteria can better resist engulfment or survive intracellularly once engulfed [7]. Taking it a step further, co-culturing prey bacteria with predatory protists selects for longer bacterial filaments [45]. This appears to be a regulated response to the protist threat, as bacteria separated from the co-culture by a permeable membrane also increase in length [46]. In addition, the actinobacterium Streptomyces coelicolor undergoes multicellular development upon exposure to predatory Myхососcus xanthus [47]. Predation resistance has also been observed in forms of simple multicellularity in algae $[32,48]$, suggesting a more general role in the evolution of multicellularity.

The last advantage of multicellularity we will discuss here is one of the reasons this is such an interesting phenomenon to study: cell specialization afforded by differentiation. Division of labor, whether within an organism or a society, leads to more efficient production and utilization of resources. The classic example of this comes from filaments of the cyanobacterium Anabaena, which can carry out both photosynthesis and nitrogen fixation. Due to the chemical incompatibility of these two processes, however, they must be spatially separated into cells specialized for each purpose [8]. An even more extreme example is the programmed cell death that occurs in the development of many bacteria. The death of some cells can serve the interests of the greater community, for example to provide extra nutrients [49,50], create raised structures that increase surface area and thus nutrient exposure [51], or fragment filaments to create spore-like propagules [50]. Additionally, division of labor allows a group of cells acting with a common interest to engage in bet-hedging strategies, allowing some cells to survive even the worst conditions [21].

\section{Origins of bacterial multicellularity}

The ubiquity of multicellular bacteria creates a sense that there must be a common element that allowed for all the independent incidences. Biofilms especially (in their loosest definition at least) seem to be the rule among bacteria rather than the exception. Is this a remarkable example of convergent evolution, or did an ancient ancestor in the trunk of the tree of life evolve something that primed its descendants to evolve multicellular lifestyles?

The prevalence of functionally analogous components and mechanisms used by multicellular organisms may argue for descent from a common ancestral toolbox. These include extracellular matrixes composed of polysaccharides, nucleic acids, and proteins [19]; quorum sensing-mediated triggering of multicellular states [15]; control by regulatory molecules such as cyclic di-GMP, signaling kinases, and phosphate-binding domains [5254]; transmembrane adhesion proteins [33]; and the presence of spores or spore-like cells [50]. Complicating the matter of conservation is widespread horizontal gene transfer throughout the microbial world, which some have suggested may play a bigger role in bacterial evolution than classic mechanisms like gene duplication [55].

However, these commonalities are mostly only functionally analogous, and therefore may instead support convergence towards a successful strategy. Archaeal biofilms, for example, 
contain many of the same features as bacteria biofilms: cell differentiation, filamentation, and even the same general matrix components [56-58]. The same can be said of deceptively similar morphological structures like fruiting bodies in myxobacteria, which resemble the fruiting bodies formed by many amoeba species [59]. These structures are physically similar and are even thought to serve the same purpose (spore dispersal), yet share no underlying homology other than cell motility. This could indicate that when the initiating factor is starvation and the end goal is escape from an adverse situation, the constraints on evolution are more relaxed and more tolerant of elaborate pathways inserted upstream of spore formation (Figure 1A). This would free the organism to explore more phenotype space, which may have allowed these disparate species to arrive at similar configurations.

Some of the biggest pieces of evidence suggesting that multicellularity evolved independently are the different kin discrimination systems found in different species. Kin discrimination is used to resolve potential social conflicts that arise when forming a higher level of organization from smaller individual units that may have selfish interests [20]. Great care is thus taken to ensure that developing multicellular bodies interact only with genetic relatives [60-62], but the mechanisms behind this behavior are diverse. In M. xanthus biofilms, portions of the outer membrane are only exchanged with cells containing the same allele of TraA, a divergent transmembrane protein that binds to its cognate version on the neighboring cell [63]. Proteus mirabilis, however, uses a Type 6 secretion system (T6SS) with a variety of effectors and immunity genes to distinguish friend from foe within swarms [64-66]. Bacillus subtilis meanwhile is a gram-positive bacterium lacking a T6SS apparatus and so instead uses a plethora of secreted antimicrobials to determine relatedness (Kolter and Mandic-Mulec labs, unpublished data). Kin discrimination in eukaryotes is similarly diverse, but the mechanisms uncovered so far make use of polymorphic immunoglobin-like domains in otherwise-nonhomologous transmembrane proteins to genotype an encountered cell [67-69]. The fact that allorecognition systems, which are theoretically necessary to maintain a multicellular lifestyle, clearly evolved independently strongly suggests that these species diverged before they developed the capacity for multicellularity. If this reasoning is sound, it implies that multicellularity has evolved not just dozens [70] but possibly hundreds of times.

If it did indeed arise so many separate times, how might the evolutionary path to multicellularity have proceeded? One possibility is through elaboration of a pre-existing attachment behavior (Figure 1B). In an environment of scarce resources, it is beneficial to stay put once nutrients are located. If an organism has developed an ability to attach to a surface for this purpose, subsequent mutations that generate a protective covering (i.e. a rudimentary matrix or other type of connective structure) would be advantageous and provide stress resistance. Over time, these adjoining cells might begin to communicate and coordinate their behavior, sending them down the road of a multicellular existence.

Another possibility is motivated by an exception to the above statement that few mechanisms behind multicellularity are conserved. Many bacteria use the same pathway to initiate filamentation: the SOS response [7]. Upon experiencing DNA damage, a cell division inhibitor is expressed and prevents septation by blocking polymerization of FtsZ [71]. This prevents daughter cells from inheriting damaged genomes, and its high degree of 
conservation across phyla may be indicative of its ancestral nature [7]. However, many bacteria have co-opted the SOS response to induce filamentation outside of the context of DNA damage, including protection against phagocytosis (Figure 1C). Use of the SOS pathway may have similarly been co-opted by the very first multicellular organisms billions of years ago, which, as discussed below, may have been filamentous bacteria.

\section{Is multicellularity inevitable?}

Despite the lack of definite underpinnings that facilitated the repeated evolution of multicellularity, it is still by far the most common evolutionary leap. This simple observation demands the question: is multicellularity inevitable? Is this particular organization of smaller component parts into a greater whole so easy and advantageous that every biosphere in the universe will have it? Or were the conditions on Earth and the layout of the first cells special in some way that is not guaranteed to occur?

Regarding the ease of the evolution of multicellularity, there are some indications that it may be a relatively straightforward advancement. Early modeling experiments showed that simple versions of multicellular hallmarks like cell differentiation, development, and a dedicated germ line can arise as a consequence of dynamic cellular contents [72]. More tellingly, experimental evolution has been used to evolve various multicellular traits in the laboratory. Manual selection for flocculation in bacteria, yeast, and algae has produced clumps of attached cells with some fairly advanced characteristics, even including apoptosis of certain cells to break up big clumps [73-76]. Additionally, Burkholderia cenocepacia can evolve a surface-attached biofilm lifestyle with complex morphologies quickly and frequently, apparently due to only a few convergent genetic changes [77]. These experiments show that multicellularity can be readily achieved, though it should be noted that the selection used in the lab is likely significantly stronger than anything encountered in the wild.

The fossil record, though scant, is in accord with the notion that multicellularity can be rapidly evolved. Stromatolites of filamentous cells can be clearly dated to over 2 billion years ago $[10,78,79]$ and perhaps as long ago as 3.5 billion years [80-83]. Some of these filaments even show some signs of differentiation [10-12]. Moreover, phylogenetic analyses argue that the ancestor to most extant cyanobacteria, including the majority of unicellular species, was multicellular [84] and evolved around 2.4 to 3.1 billion years ago [85]. This puts the evolution of multicellularity not too long after the Earth cooled down enough to support any life at all. On geological and evolutionary scales, then, the advent of multicellular organisms may have occurred very soon after the formation of unicellular organisms.

How does this information affect our view of multicellularity in the greater universe? Terrestrial multicellularity clearly evolved early and often, which is encouraging for the existence of complex life on other planets. Moreover, multicellularity is apparently one of those rare benchmarks in the random path of evolution that many separate lineages are able to stumble on. It therefore seems reasonable to expect that any biosphere with a rich diversity of species and environments should have at least rudimentary forms of 
multicellularity. The independent instances of multicellularity also make this expectation mercifully free from the anthropic principle, as the bacterial forms discussed here would still exist without us to ruminate over them.

\section{Acknowledgments}

N.A.L. is a fellow of the Helen Hay Whitney Foundation. Work on multicellularity in our laboratory is funded by grants from the National Institutes of Health (GM58218) and the John Templeton Foundational Questions in Evolutionary Biology Program.

\section{References}

1. Maynard Smith, J.; Szathmáry, E. The major transitions in evolution. Oxford ; New York: W.H. Freeman Spektrum; 1995.

2. Shapiro, JA. Bacteria As Multicellular Organisms. Vol. 258. Scientific American; 1988. p. 82-89.

3. Sagulenko E, Morgan GP, Webb RI, Yee B, Lee KC, Fuerst JA. Structural studies of planctomycete Gemmata obscuriglobus support cell compartmentalisation in a bacterium. PLoS One. 2014; 9:e91344. [PubMed: 24632833]

4. Ryan JF, Pang K, Schnitzler CE, Nguyen AD, Moreland RT, Simmons DK, Koch BJ, Francis WR, Havlak P, Program NCS, et al. The genome of the ctenophore Mnemiopsis leidyi and its implications for cell type evolution. Science. 2013; 342:1242592. [PubMed: 24337300]

5. Moroz LL, Kocot KM, Citarella MR, Dosung S, Norekian TP, Povolotskaya IS, Grigorenko AP, Dailey C, Berezikov E, Buckley KM, et al. The ctenophore genome and the evolutionary origins of neural systems. Nature. 2014; 510:109-114. [PubMed: 24847885]

6. Janik VM. Cognitive skills in bottlenose dolphin communication. Trends Cogn Sci. 2013; 17:157159. [PubMed: 23518158]

7. Justice SS, Hunstad DA, Cegelski L, Hultgren SJ. Morphological plasticity as a bacterial survival strategy. Nat Rev Microbiol. 2008; 6:162-168. [PubMed: 18157153]

8. Flores E, Herrero A. Compartmentalized function through cell differentiation in filamentous cyanobacteria. Nat Rev Microbiol. 2010; 8:39-50. [PubMed: 19966815]

9. Schopf JW, Kudryavtsev AB, Czaja AD, Tripathi AB. Evidence of Archean life: Stromatolites and microfossils. Precambrian Research. 2007; 158:141-155.

10. Amard B, Bertrand-Sarfati J. Microfossils in 2000 Ma old cherty stromatolites of the Franceville Group, Gabon. Precambrian Research. 1997; 81:197-221.

11. Golubic S, Sergeev VN, Knoll AH. Mesoproterozoic Archaeoellipsoides: akinetes of heterocystous cyanobacteria. Lethaia. 1995; 28:285-298. [PubMed: 11539549]

12. Srivastava P. Vindhyan akinites: an indicator of mesoproterozoic biospheric evolution. Orig Life Evol Biosph. 2005; 35:175-185. [PubMed: 16010997]

13. Vlamakis H, Chai Y, Beauregard P, Losick R, Kolter R. Sticking together: building a biofilm the Bacillus subtilis way. Nat Rev Microbiol. 2013; 11:157-168. [PubMed: 23353768]

14. Jones BV, Young R, Mahenthiralingam E, Stickler DJ. Ultrastructure of Proteus mirabilis swarmer cell rafts and role of swarming in catheter-associated urinary tract infection. Infect Immun. 2004; 72:3941-3950. [PubMed: 15213138]

15. Lopez D, Vlamakis H, Kolter R. Biofilms. Cold Spring Harb Perspect Biol. 2010; 2:a000398. [PubMed: 20519345]

16. Entcheva-Dimitrov P, Spormann AM. Dynamics and control of biofilms of the oligotrophic bacterium Caulobacter crescentus. J Bacteriol. 2004; 186:8254-8266. [PubMed: 15576774]

17. Klausen M, Aaes-Jorgensen A, Molin S, Tolker-Nielsen T. Involvement of bacterial migration in the development of complex multicellular structures in Pseudomonas aeruginosa biofilms. Mol Microbiol. 2003; 50:61-68. [PubMed: 14507363]

18. Goldman B, Bhat S, Shimkets LJ. Genome evolution and the emergence of fruiting body development in Myxococcus xanthus. PLoS One. 2007; 2:e1329. [PubMed: 18159227] 
19. Flemming HC, Wingender J. The biofilm matrix. Nat Rev Microbiol. 2010; 8:623-633. [PubMed: 20676145]

20. West SA, Griffin AS, Gardner A, Diggle SP. Social evolution theory for microorganisms. Nat Rev Microbiol. 2006; 4:597-607. [PubMed: 16845430]

*21. Boles BR, Thoendel M, Singh PK. Self-generated diversity produces "insurance effects" in biofilm communities. Proc Natl Acad Sci U S A. 2004; 101:16630-16635. Bet-hedging in biofilms protects against variable environments. [PubMed: 15546998]

22. Abreu F, Martins JL, Silveira TS, Keim CN, de Barros HG, Filho FJ, Lins U. 'Candidatus Magnetoglobus multicellularis', a multicellular, magnetotactic prokaryote from a hypersaline environment. Int J Syst Evol Microbiol. 2007; 57:1318-1322. [PubMed: 17551050]

23. Chen YR, Zhang R, Du HJ, Pan HM, Zhang WY, Zhou K, Li JH, Xiao T, Wu LF. A novel species of ellipsoidal multicellular magnetotactic prokaryotes from Lake Yuehu in China. Environ Microbiol. 2014

24. Keim CN, Martins JL, Abreu F, Rosado AS, de Barros HL, Borojevic R, Lins U, Farina M. Multicellular life cycle of magnetotactic prokaryotes. FEMS Microbiol Lett. 2004; 240:203-208. [PubMed: 15522508]

25. Lefevre CT, Abreu F, Lins U, Bazylinski DA. Nonmagnetotactic multicellular prokaryotes from low-saline, nonmarine aquatic environments and their unusual negative phototactic behavior. Appl Environ Microbiol. 2010; 76:3220-3227. [PubMed: 20363801]

26. Simmons SL, Edwards KJ. Unexpected diversity in populations of the many-celled magnetotactic prokaryote. Environ Microbiol. 2007; 9:206-215. [PubMed: 17227425]

27. Zhang R, Chen YR, Du HJ, Zhang WY, Pan HM, Xiao T, Wu LF. Characterization and phylogenetic identification of a species of spherical multicellular magnetotactic prokaryotes that produces both magnetite and greigite crystals. Res Microbiol. 2014; 165:481-489. [PubMed: 25086260]

28. Zhou K, Zhang WY, Yu-Zhang K, Pan HM, Zhang SD, Zhang WJ, Yue HD, Li Y, Xiao T, Wu LF. A novel genus of multicellular magnetotactic prokaryotes from the Yellow Sea. Environ Microbiol. 2012; 14:405-413. [PubMed: 21978297]

29. Zhou K, Zhang WY, Pan HM, Li JH, Yue HD, Xiao T, Wu LF. Adaptation of spherical multicellular magnetotactic prokaryotes to the geochemically variable habitat of an intertidal zone. Environ Microbiol. 2013; 15:1595-1605. [PubMed: 23279048]

30. Abreu F, Silva KT, Martins JL, Lins U. Cell viability in magnetotactic multicellular prokaryotes. Int Microbiol. 2006; 9:267-272. [PubMed: 17236160]

31. Keim CN, Abreu F, Lins U, Lins de Barros H, Farina M. Cell organization and ultrastructure of a magnetotactic multicellular organism. J Struct Biol. 2004; 145:254-262. [PubMed: 14960376]

32. Kirk DL. Seeking the Ultimate and Proximate Causes of Volvox Multicellularity and Cellular Differentiation. Integrative and Comparative Biology. 2003; 43:247-253. [PubMed: 21680429]

*33. Abreu F, Morillo V, Nascimento FF, Werneck C, Cantao ME, Ciapina LP, de Almeida LG, Lefevre CT, Bazylinski DA, de Vasconcelos AT, et al. Deciphering unusual uncultured magnetotactic multicellular prokaryotes through genomics. ISME J. 2014; 8:1055-1068. First genome of an MMP reveals adhesion genes and means of culturing the bacteria. [PubMed: 24196322]

34. Young KD. The selective value of bacterial shape. Microbiol Mol Biol Rev. 2006; 70:660-703. [PubMed: 16959965]

35. Niklas KJ, Cobb ED, Kutschera U. Did meiosis evolve before sex and the evolution of eukaryotic life cycles? Bioessays. 2014; 36:1091-1101. [PubMed: 25143284]

36. Marcon E, Moens PB. The evolution of meiosis: recruitment and modification of somatic DNArepair proteins. Bioessays. 2005; 27:795-808. [PubMed: 16015600]

37. Berleman JE, Chumley T, Cheung P, Kirby JR. Rippling is a predatory behavior in Myxococcus xanthus. J Bacteriol. 2006; 188:5888-5895. [PubMed: 16885457]

38. Dayel MJ, King N. Prey capture and phagocytosis in the choanoflagellate Salpingoeca rosetta. PLoS One. 2014; 9:e95577. [PubMed: 24806026]

*39. Pfeffer C, Larsen S, Song J, Dong M, Besenbacher F, Meyer RL, Kjeldsen KU, Schreiber L, Gorby YA, El-Naggar MY, et al. Filamentous bacteria transport electrons over centimetre 
distances. Nature. 2012; 491:218-221. Unconventional benefit of multicellularity: spanning a redox gradient and passing electrons along the filament. [PubMed: 23103872]

40. Wilking JN, Zaburdaev V, De Volder M, Losick R, Brenner MP, Weitz DA. Liquid transport facilitated by channels in Bacillus subtilis biofilms. Proc Natl Acad Sci U S A. 2013; 110:848852. [PubMed: 23271809]

41. Kim W, Racimo F, Schluter J, Levy SB, Foster KR. Importance of positioning for microbial evolution. Proc Natl Acad Sci U S A. 2014; 111:E1639-1647. [PubMed: 24715732]

42. Koschwanez JH, Foster KR, Murray AW. Sucrose utilization in budding yeast as a model for the origin of undifferentiated multicellularity. PLoS Biol. 2011; 9:e1001122. [PubMed: 21857801]

43. Koschwanez JH, Foster KR, Murray AW. Improved use of a public good selects for the evolution of undifferentiated multicellularity. Elife. 2013; 2:e00367. [PubMed: 23577233]

44. Rosenberg E, Keller KH, Dworkin M. Cell density-dependent growth of Myxococcus xanthus on casein. J Bacteriol. 1977; 129:770-777. [PubMed: 402357]

**45. Jurgens K, Matz C. Predation as a shaping force for the phenotypic and genotypic composition of planktonic bacteria. Antonie Van Leeuwenhoek. 2002; 81:413-434. [PubMed: 12448740]

$* * 46$. Corno G, Jurgens K. Direct and indirect effects of protist predation on population size structure of a bacterial strain with high phenotypic plasticity. Appl Environ Microbiol. 2006; 72:78-86. Demonstration of filamentation as a direct response to the presense of a predator. [PubMed: 16391028]

47. Perez J, Munoz-Dorado J, Brana AF, Shimkets LJ, Sevillano L, Santamaria RI. Myxococcus xanthus induces actinorhodin overproduction and aerial mycelium formation by Streptomyces coelicolor. Microb Biotechnol. 2011; 4:175-183. [PubMed: 21342463]

48. Boraas M, Seale D, Boxhorn J. Phagotrophy by a flagellate selects for colonial prey: A possible origin of multicellularity. Evolutionary Ecology. 1998; 12:153-164.

49. Gonzalez-Pastor JE, Hobbs EC, Losick R. Cannibalism by sporulating bacteria. Science. 2003; 301:510-513. [PubMed: 12817086]

50. Claessen D, Rozen DE, Kuipers OP, Sogaard-Andersen L, van Wezel GP. Bacterial solutions to multicellularity: a tale of biofilms, filaments and fruiting bodies. Nat Rev Microbiol. 2014; 12:115-124. [PubMed: 24384602]

51. Asally M, Kittisopikul M, Rue P, Du Y, Hu Z, Cagatay T, Robinson AB, Lu H, Garcia-Ojalvo J, Suel GM. Localized cell death focuses mechanical forces during 3D patterning in a biofilm. Proc Natl Acad Sci U S A. 2012; 109:18891-18896. [PubMed: 23012477]

52. Romling U, Galperin MY, Gomelsky M. Cyclic di-GMP: the first 25 years of a universal bacterial second messenger. Microbiol Mol Biol Rev. 2013; 77:1-52. [PubMed: 23471616]

53. Perez J, Castaneda-Garcia A, Jenke-Kodama H, Muller R, Munoz-Dorado J. Eukaryotic-like protein kinases in the prokaryotes and the myxobacterial kinome. Proc Natl Acad Sci U S A. 2008; 105:15950-15955. [PubMed: 18836084]

54. Schneiker S, Perlova O, Kaiser O, Gerth K, Alici A, Altmeyer MO, Bartels D, Bekel T, Beyer S, Bode E, et al. Complete genome sequence of the myxobacterium Sorangium cellulosum. Nat Biotechnol. 2007; 25:1281-1289. [PubMed: 17965706]

55. Treangen TJ, Rocha EP. Horizontal transfer, not duplication, drives the expansion of protein families in prokaryotes. PLoS Genet. 2011; 7:e1001284. [PubMed: 21298028]

56. Chimileski S, Franklin MJ, Papke R. Biofilms formed by the archaeon. BMC Biol. 2014; 12:65. [PubMed: 25124934]

57. Frols S. Archaeal biofilms: widespread and complex. Biochem Soc Trans. 2013; 41:393-398. [PubMed: 23356317]

58. Frols S, Dyall-Smith M, Pfeifer F. Biofilm formation by haloarchaea. Environ Microbiol. 2012; 14:3159-3174. [PubMed: 23057712]

59. Lahr DJ, Laughinghouse HDt, Oliverio AM, Gao F, Katz LA. How discordant morphological and molecular evolution among microorganisms can revise our notions of biodiversity on Earth. Bioessays. 2014; 36:950-959. [PubMed: 25156897]

60. Dienes L. Reproductive processes in Proteus cultures. Proc Soc Exp Biol Med. 1946; 63:265-270. [PubMed: 20277719] 
61. Ostrowski EA, Katoh M, Shaulsky G, Queller DC, Strassmann JE. Kin discrimination increases with genetic distance in a social amoeba. PLoS Biol. 2008; 6:e287. [PubMed: 19067487]

62. Vos M, Velicer GJ. Social conflict in centimeter-and global-scale populations of the bacterium Myxococcus xanthus. Curr Biol. 2009; 19:1763-1767. [PubMed: 19879146]

*63. Pathak DT, Wei X, Dey A, Wall D. Molecular recognition by a polymorphic cell surface receptor governs cooperative behaviors in bacteria. PLoS Genet. 2013; 9:e1003891. [PubMed: 24244178]

*64. Alteri CJ, Himpsl SD, Pickens SR, Lindner JR, Zora JS, Miller JE, Arno PD, Straight SW, Mobley HL. Multicellular bacteria deploy the type VI secretion system to preemptively strike neighboring cells. PLoS Pathog. 2013; 9:e1003608. [PubMed: 24039579]

*65. Wenren LM, Sullivan NL, Cardarelli L, Septer AN, Gibbs KA. Two independent pathways for self-recognition in Proteus mirabilis are linked by type VI-dependent export. MBio. 2013; 4 Diverse molecular mechanisms underlying kin discrimination in two bacterium species.

66. Sullivan NL, Septer AN, Fields AT, Wenren LM, Gibbs KA. The Complete Genome Sequence of Proteus mirabilis Strain BB2000 Reveals Differences from the P. mirabilis Reference Strain. Genome Announc. 2013; 1

67. Benabentos R, Hirose S, Sucgang R, Curk T, Katoh M, Ostrowski EA, Strassmann JE, Queller DC, Zupan B, Shaulsky G, et al. Polymorphic members of the lag gene family mediate kin discrimination in Dictyostelium. Curr Biol. 2009; 19:567-572. [PubMed: 19285397]

68. Nicotra ML, Powell AE, Rosengarten RD, Moreno M, Grimwood J, Lakkis FG, Dellaporta SL, Buss LW. A hypervariable invertebrate allodeterminant. Curr Biol. 2009; 19:583-589. [PubMed: 19303297]

69. Voskoboynik A, Newman AM, Corey DM, Sahoo D, Pushkarev D, Neff NF, Passarelli B, Koh W, Ishizuka KJ, Palmeri KJ, et al. Identification of a colonial chordate histocompatibility gene. Science. 2013; 341:384-387. [PubMed: 23888037]

70. Fisher RM, Cornwallis CK, West SA. Group formation, relatedness, and the evolution of multicellularity. Curr Biol. 2013; 23:1120-1125. [PubMed: 23746639]

71. Mukherjee A, Cao C, Lutkenhaus J. Inhibition of FtsZ polymerization by SulA, an inhibitor of septation in Escherichia coli. Proc Natl Acad Sci U S A. 1998; 95:2885-2890. [PubMed: 9501185]

72. Furusawa C, Kaneko K. Origin of multicellular organisms as an inevitable consequence of dynamical systems. Anat Rec. 2002; 268:327-342. [PubMed: 12382328]

73. Ferguson GC, Bertels F, Rainey PB. Adaptive divergence in experimental populations of Pseudomonas fluorescens. V. Insight into the niche specialist fuzzy spreader compels revision of the model Pseudomonas radiation. Genetics. 2013; 195:1319-1335. [PubMed: 24077305]

**74. Oud B, Guadalupe-Medina V, Nijkamp JF, de Ridder D, Pronk JT, van Maris AJ, Daran JM. Genome duplication and mutations in ACE2 cause multicellular, fast-sedimenting phenotypes in evolved Saccharomyces cerevisiae. Proc Natl Acad Sci U S A. 2013; 110:E4223-4231. [PubMed: 24145419]

**75. Ratcliff WC, Denison RF, Borrello M, Travisano M. Experimental evolution of multicellularity. Proc Natl Acad Sci U S A. 2012; 109:1595-1600. These groups used experimental evolution to generate complex multicellular yeast in short timespans. [PubMed: 22307617]

76. Ratcliff WC, Herron MD, Howell K, Pentz JT, Rosenzweig F, Travisano M. Experimental evolution of an alternating uni- and multicellular life cycle in Chlamydomonas reinhardtii. Nat Commun. 2013; 4:2742. [PubMed: 24193369]

77. Traverse CC, Mayo-Smith LM, Poltak SR, Cooper VS. Tangled bank of experimentally evolved Burkholderia biofilms reflects selection during chronic infections. Proc Natl Acad Sci U S A. 2013; 110:E250-259. [PubMed: 23271804]

78. Hofmann HJ. Precambrian Microflora, Belcher Islands, Canada: Significance and Systematics. Journal of Paleontology. 1976; 50:1040-1073.

79. Rasmussen B, Fletcher IR, Brocks JJ, Kilburn MR. Reassessing the first appearance of eukaryotes and cyanobacteria. Nature. 2008; 455:1101-1104. [PubMed: 18948954]

80. Schopf JW. Microfossils of the Early Archean Apex chert: new evidence of the antiquity of life. Science. 1993; 260:640-646. [PubMed: 11539831]

81. Tice MM, Lowe DR. Photosynthetic microbial mats in the 3,416-Myr-old ocean. Nature. 2004; 431:549-552. [PubMed: 15457255] 
82. Walsh MM. Microfossils and possible microfossils from the Early Archean Onverwacht Group, Barberton Mountain Land, South Africa. Precambrian Res. 1992; 54:271-293. [PubMed: 11540926]

83. Westall F, de Ronde CE, Southam G, Grassineau N, Colas M, Cockell C, Lammer H. Implications of a 3.472-3. 333 Gyr-old subaerial microbial mat from the Barberton greenstone belt, South Africa for the UV environmental conditions on the early Earth. Philos Trans R Soc Lond B Biol Sci. 2006; 361:1857-1875. [PubMed: 17008224]

**84. Schirrmeister BE, Antonelli A, Bagheri HC. The origin of multicellularity in cyanobacteria. BMC Evol Biol. 2011; 11:45. [PubMed: 21320320]

**85. Schirrmeister BE, de Vos JM, Antonelli A, Bagheri HC. Evolution of multicellularity coincided with increased diversification of cyanobacteria and the Great Oxidation Event. Proc Natl Acad Sci U S A. 2013; 110:1791-1796. Using phylogenetic reconstruction, these papers determine that multicellularity is likely the ancestral state of extant cyanobacteria, and evolved up to 3 billion years ago. [PubMed: 23319632] 


\section{Highlights}

- Many bacteria have a multicellular phase of their lifecycle, which fall into three broad categories based on shape and mechanism of formation.

- A number of pressures may have selected for multicellularity, including physicochemical stress, nutrient scarcity, predation, and environmental variability.

- Despite many shared features between species, current evidence suggests each instance of multicellularity evolved independently.

- The evolution of multicellular bacteria may have been relatively rapid, suggesting it is not just a contingent feature of our biosphere. 


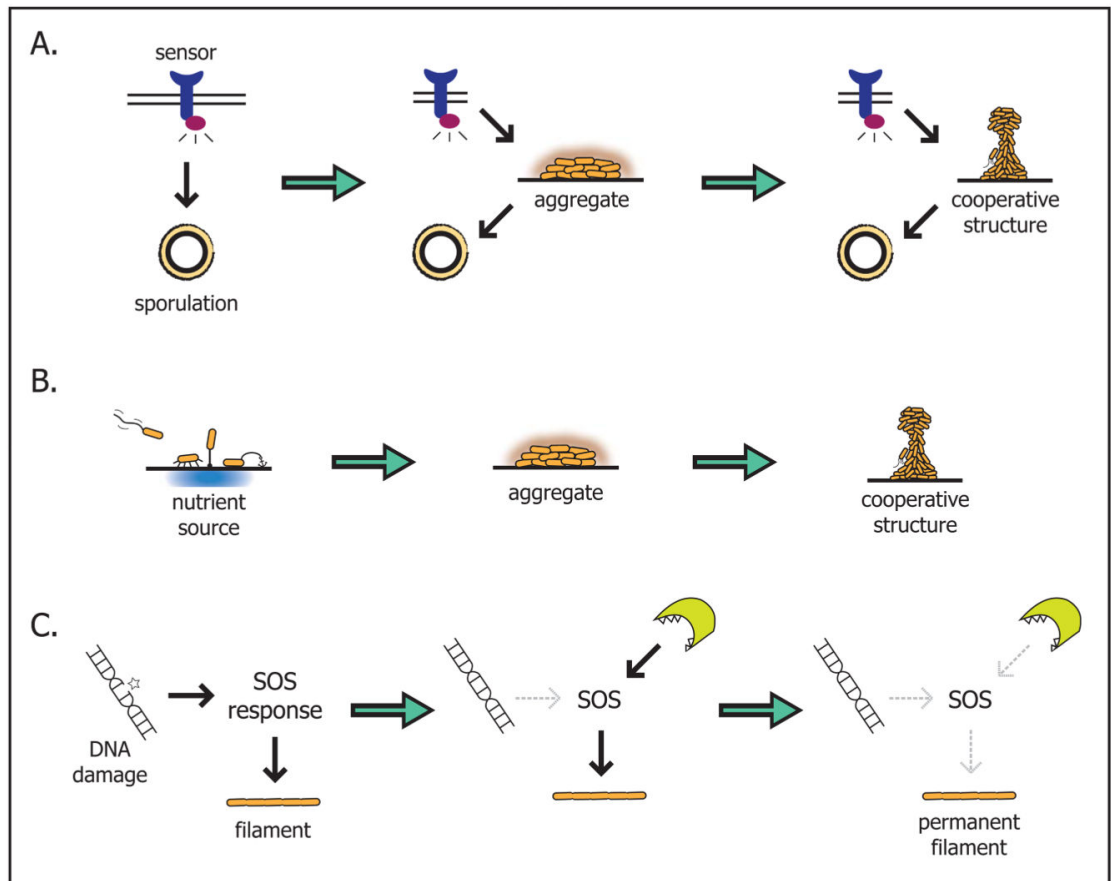

Figure 1.

Hypothetical evolutionary paths from unicellular to multicellular lifestyles. A) Elaboration of a pre-existing sporulation pathway by insertion of aggregation and aerial structure formation between the stress sensing and spore development. B) Attachment to regions of high nutrients may have spurred the development of a protective matrix, forcing a communal existence. C) The SOS response pathway can induce filamentation independent of DNA damage, for example by the presence of a predator; co-option of the SOS pathway may have lead to a permanent filamentous lifestyle. 


\section{Table 1}

General classes of multicellular bacteria.

\begin{tabular}{|l|l|l|}
\hline Class & Features & Examples \\
\hline Filaments & $\begin{array}{l}\text { Cell differentiation, patterning via intercellular signaling, clonal } \\
\text { origin, first known instance of multicellularity }\end{array}$ & $\begin{array}{l}\text { Cyanobacteria, Actinomycetes, Chloroflexi, } \\
\text { Desulfobulbaceae, Beggiatoa, Thioploca }\end{array}$ \\
\hline Aggregates & $\begin{array}{l}\text { Cell differentiation, developmental program, intercellular } \\
\text { signaling, extracellular matrix, can be clonal or non-clonal }\end{array}$ & Biofilms and swarms in many species \\
\hline $\begin{array}{l}\text { MMPs (multicellular } \\
\text { magnetotactic } \\
\text { prokaryotes) }\end{array}$ & $\begin{array}{l}\text { No observed unicellular stage, apparent tight cell-cell junctions, } \\
\text { coordinated flagellar movement, division by fission of entire } \\
\text { structure }\end{array}$ & $\begin{array}{l}\text { Candidatus Magnetoglobus multicellularis, } \mathrm{Ca} . \\
\text { Magnetomorum litorale, } \mathrm{Ca} \text {. Magnetananas } \\
\text { tsingtaoensis, } \mathrm{Ca} \text {. Magnetomorum tsingtaoroseum, } \\
\text { Ca. Magnetananas rongchenensis, } \mathrm{Ca} . \\
\text { Magnetomorum rongchengroseum }\end{array}$ \\
\hline
\end{tabular}

